\title{
自動泡洗浄付き介護用トイレシステムの開発とその評価
}

所晃史 ${ }^{* 1}$ ，小林 宏 ${ }^{* 1}$

\section{Development and evaluation of toilet system for caring with automatic washing using foam}

\author{
Koushi TOKORO ${ }^{* 1}$ and Hiroshi KOBAYASHI ${ }^{* 1}$ \\ ${ }^{* 1}$ Tokyo University of Science, Department of Mechanical Engineering, \\ 6-3-1 Niijuku, Katsushika-ku, Tokyo 125-8585, Japan
}

\section{Received 27 October 2014}

\begin{abstract}
Japan entered a super-aged society, and an excretion care of nursing care is a serious social problem. The excretion care causes physical and mental stress to both caregivers and recipients. In this study, we have been developing new nursing care equipment for reducing the stress of the excretion care. The equipment consists of "Support system” and "Toilet system". The support system assists the recipient to get up from a bed and walk without help, and the toilet system assists of toileting. The toilet system can detect the position of an anus by using an infrared thermal camera, prevent odor dispersion by attaching the device to the buttocks, and capture feces in a bag. And wiping machine of the device can wash an anus using foam. Here we investigated the estimation experiment which checks the efficacy of foam for washing the anus using an artificial buttocks and an artificial stool. Comparing the number of wipes and residual percentage of filth on the artificial buttocks after the device cleans the buttocks. In the result about whether or not foam is present, the number of wipes and the residual percentage when use foam was less than half when don't use. Therefore, we confirmed that using foam removes more fecal filth.
\end{abstract}

Key words : Care support, Medical and welfare assistance, Old elderly, Toileting assistance, Toilet

\section{1. 緒言}

わが国は超高齢社会に突入し, 2012 年に 65 歳以上の高齢者の人口は過去最高の 3,079 万人となり, 総人口に占 める割合は 24.1\%となった（厚生労働省，2013b)。また介護現場では，要介護および要支援認定の高齢者が 2012 年度に約 533 万人，高齢者人口の約 $17.3 \%$ となっている。そして，自ら移動することが困難であり，また食事や 排泄に介護が必要である要介護 3 以上の高齢者は約 200 万人いるとされている（厚生労働省，2013a）。介護が必 要な高齢者が増えるなか，介護現場が抱える問題の一つとして排泄介護があげられる。排泄介護では，介護者が 被介護者を移乗するために身体を持ち上げるなどの身体的な負担があることに加え，介護者，被介護者双方が精 神的負担を感じていることが報告されている（菊池他，2011）（吉本，2008）。特に被介護者は，異性に排泄介護 を頼みたくない，排泄支援自体を受けたくないなどの葛藤がある（吉本，2008）。そのため，両者の負担を軽減す るような排泄処理装置（トイレシステム）の開発は，超高齢社会に不可欠な要素であると著者らは考えている.

排泄介護を支援するためのトイレやアシスト装置の開発はいくつか行われており，介護者の身体的負担を減ら すため被介護者の便座への移乗を支援する装置（石川，高橋，2003）（Homma，et al., 2009）や，移動中の転倒や 失禁などを防ぐためにトイレ自体が自立して被介護者のところまで移動するトイレ装置がある（上野他，2008）

(Yukawa, et al., 2010). 寝たきりの被介護者の場合，紙おむつが主に使用されるが，おむつ交換の手間や臭気の 問題がある（板倉他，2008）。そこで被介護者のための，寝た状態でも排泄が行える自動排泄処理装置が開発され ており，排泄時に尿と便をセンサで認識することで吸引，洗浄，乾燥を自動で行うことが可能になっている

\footnotetext{
No.14-00578 [DOI:10.1299/transjsme.14-00578], J-STAGE Advance Publication date : 27 February, 2015

*1 正員, 東京理科大学 工学部 (干125-8585 東京都葛飾区新宿 6-3-1)

E-mail of corresponding author: tokoro@kobalab.com
} 
(Fujimoto, et al., 1998)．しかし，これらの装置は介護者の負担軽減につながるが，被介護者の自立を支援するも のではなく，長期間使用すると被介護者は廃用症候群を発症し，日常生活動作（ADL）の低下につながる恐れが ある.

ところで著者らは，宇宙での使用を想定した，臀部に密着させることで，便を外に出さずに確実に回収する装 着型のトイレシステムの開発を行なってきた（所，小林，2012）（Tokoro, et al., 2012）。また，仰向けに寝ている 状態で体に装着し，体を持ち上げ，回転して直立させ，歩行を可能にする「自立生活サポートシステム」の開発 も行っている（原田，小林，2013）。そこで本研究では，これまでに開発したトイレシステムを活用しつつ，自立 生活サポートシステムと連携して, 排泄介護を支援する介護用トイレシステムの開発を行うことで, たとえほと んど寝たきりの方でも, 装置によって寝た状態から起立した状態になり, 歩行してトイレまで移動し, 排泄が行 えるようにすることを目指している，そして最終的には，生きている限り寝たきりになることなく，正しい姿勢 で歩行をし，座って排泄ができることで，QOL（生活の質）を高め，人間の尊厳を維持できるようになることを 目的としている.

介護用トイレシステムでは, サポートシステムで移動し, 便座に座ってもらった後, 自動で装置（トイレユニ ット）を臀部に密着させ，その中の収納袋に排泄を行なってもらう．排泄後は装置によって肚門の污れを自動的 に拭き取ることで，体が不自由な方でも介護者の手を借りず，肚門の洗浄が行える．このとき，秱部を装置に密 着させた状態で排泄してもらい，排泄後に排泄物の入った収納袋を熱圧着によって密閉することで，臭いの拡散 を防ぐ.

装置を臀部に密着させる際, また肛門を洗浄寸る際に, 使用者の肛門の位置を知る必要があるため, 赤外線サ 一モカメラにより検出する肛門検出システムの開発を行なった（Tokoro, et al., 2013）。これにより肛門の位置が特 定できるようになったので，本報告では，肛門の污れを装置で拭き取るための清拭機構を導入したトイレシステ ムの開発を行なった．また今回，装置により污れを取る洗浄方法として，排泄前後で肛門に泡を付着させること により, 污れを取れやすくした後, ウエットティッシュで拭き取る方法を提案し, 本システムで実装した.

本トイレシステムでは, トイレユニットに取り付けた袋の中に排泄をしてもらい, 排泄完了後に袋を取り出し, おむつなどと同様な処理方法でごみとして廃棄することを想定しており，水洗トイレのように排泄物の処理で水 を使用しない. さらに泡を利用した洗浄方法で, 水で污れを洗い流寸温水洗浄便座（ウォシュレット，シャワー トイレなど）と異なり，水をほとんど使用せずに洗浄ができる．そのため，污水の処理をすることや給排水管の 設置をする必要がない方式となっている.

以下, 本報告では, 2 章で開発した介護用トイレシステムの概要を説明し，3 章で肚門の位置を特定するための 赤外線サーモカメラを使った肚門検出システムを，4章でトイレユニットを肚門位置まで移動させる移動機構を， 5 章にトイレユニットの詳細を述べる. そして, 本研究ではトイレユニットの清拭動作で泡の利用を提案したが, その泡の有効性評価を 6 章で述べる.

\section{2. 介護用トイレシステムの概要}

介護用トイレシステムの外観を図 1 に示す．本システムは，アルミフレームの土台に，AC モータで前後に移 動する便座部分が配置されている．便座部分は，使用者が座る便座，排泄物の回収および臀部の清拭を行うトイ レユニット, トイレユニットを移動させるための移動機構, 肛門位置を検出するための赤外線サーモカメラで構 成している(図1(a)).

本システムは，壁に埋め込むなど普段は装置全体を収納することを想定しており（図 1(b)），使用前は便座部分 をしまった状態にすることで, 景観にも配慮したいと考えている. 使用時は, 図 2 のように便座部分を前に出し, 使用者が座った後, 赤外線サ一モカメラによって臀部を撮影し, 肛門検出システムにより肛門の位置を特定する. その後, 移動機構によりトイレユニットがその肛門位置に移動して臀部に密着する. 排泄時は密着したトイレユ ニット内に取り付けた袋に排泄してもらい，排泄後，泡により臀部の清拭を行う．排泄物の入った袋は，トイレ ユニット内のヒートシーラーで密閉することで, 臭いを外気に拡散しないようにした. 使用後は袋を回収し, 便 座部分を移動させて壁に収納する．袋の処理は，おむつなどと同様の方法でごみとして廃棄する. 


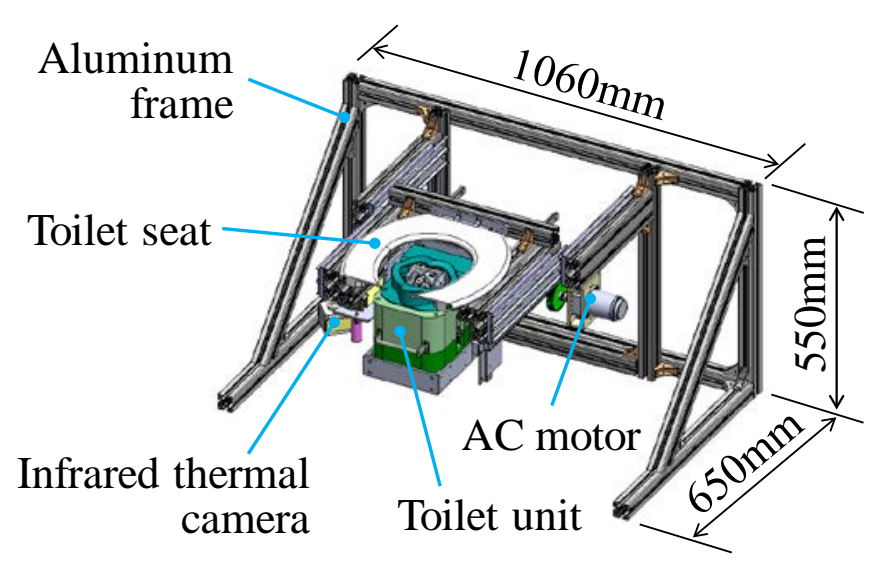

(a) Overall view

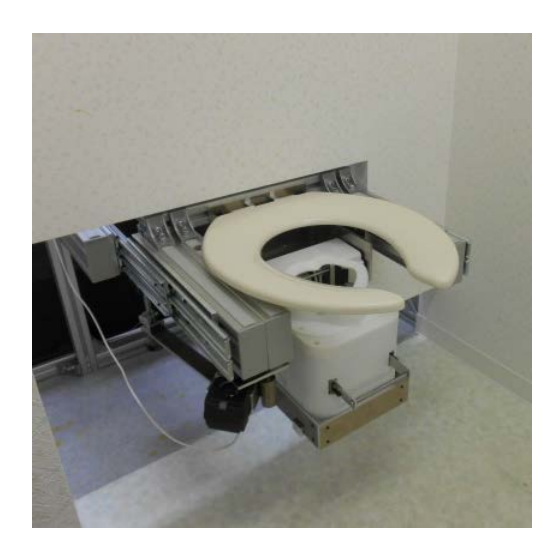

(b) Example of installation

Fig. 1 Mechanical structure of toilet system

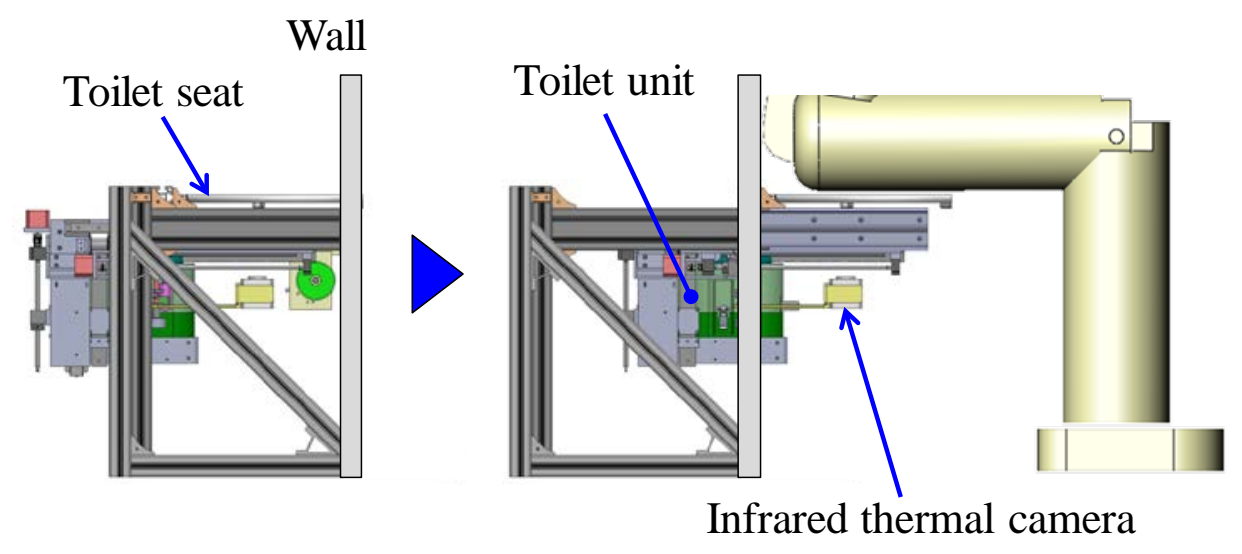

Fig. 2 Operation of the toilet system

\section{3. 肛門検出システム}

\section{$3 \cdot 1$ システム概要}

介護用トイレシステムでは，トイレユニットを肛門の位置まで移動させ，臂部に密着させた後，その中に排泄 をしてもらう，ユニットを密着させることで，臭いが外気に拡散しないようにし，便を確実に回収する．また， 泡を使った慰部の清拭を行う。このとき肛門の位置を知る必要があるため，本システムでは赤外線サーモカメラ を利用した肛門検出システムを開発した（Tokoro, et al., 2013）.

この検出システムは，体内温度に近い肛門部分とその周囲の表面温度との温度差に着目し，赤外線サーモカメ ラで測定した温度データから肛門を識別，その位置を特定している.

\section{$3 \cdot 2$ システム構成}

図 3 に肛門検出システムの構成を示寸. 赤外線サーモカメラ（チノー社製 小型熱画像センサ TP-L0260UN）で 測定した温度データをUSB 経由で PC に送り, 肛門位置の特定を行う。そして特定した位置からトイレユニット の移動距離を算出し，そのデータを移動機構のステッピングモータを制御する PIC にシリアルケーブル RS-232C を経由して転送する，その後，移動機構によりトイレユニットを肛門の位置まで移動させ，臀部に密着させる．

図 4 にトイレシステムを側面から見たときの赤外線サーモカメラの配置を示寸．赤外線サーモカメラは便座の 下にあり，臀部全体が測定できるような位置にカメラを配置した。 このとき赤外線サーモカメラは便座上面から の距離, すなわち測定距離 $D$ が $150 \mathrm{~mm}$ の位置にあり, 測定範囲は $204.45 \times 208.80 \mathrm{~mm}$, 一画素当たりの視野幅 $W$ は $4.35 \mathrm{~mm}$ となっている. 出力される熱画像の例を図 5 に示寸. 


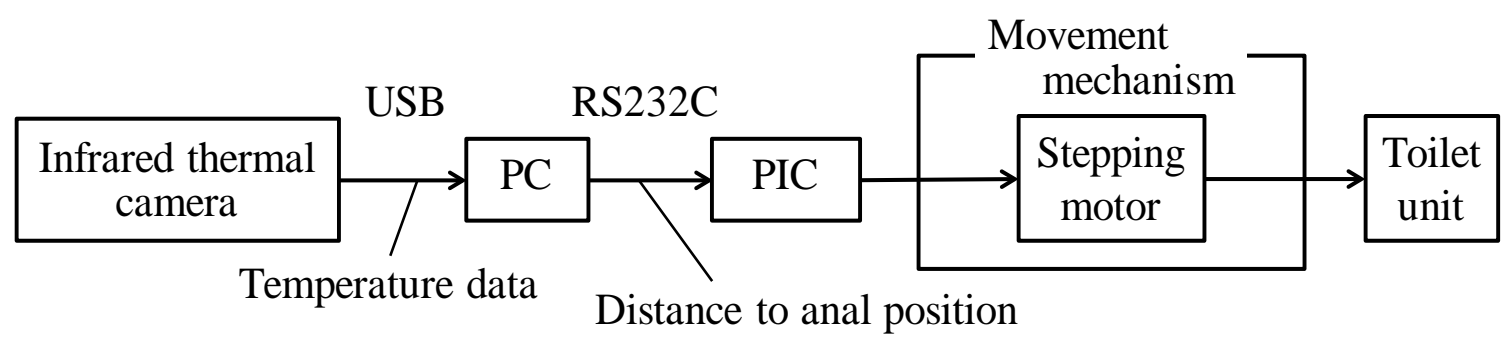

Fig. 3 System configuration

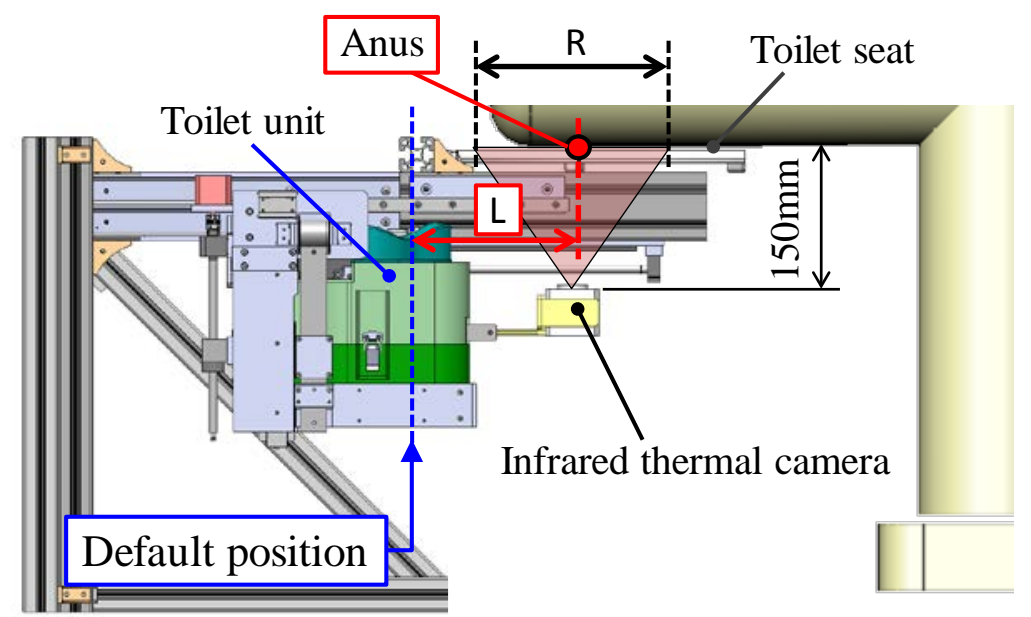

Fig. 4 Configuration of the infrared camera (sectional side view)

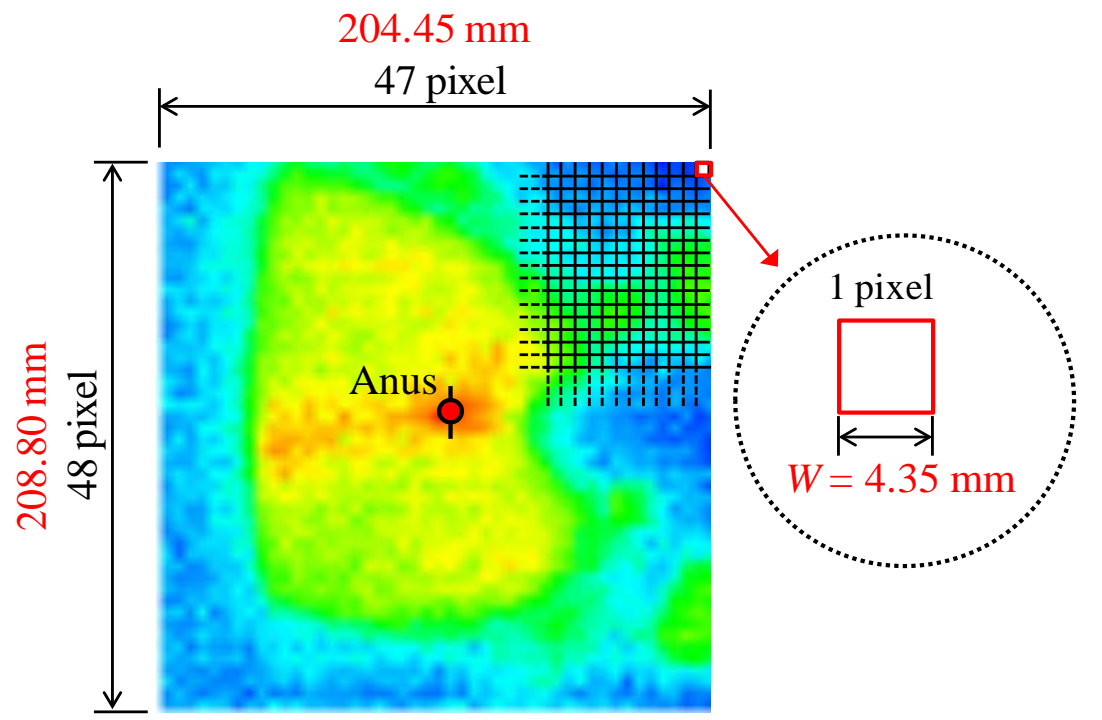

Fig. 5 Infrared thermal image of buttocks

\section{4. 移動機構}

\section{$4 \cdot 1$ 移動機構の概要}

移動機構は，トイレユニットを肛門の位置まで運び，慰部に密着させるための機構である．移動機構の初期位

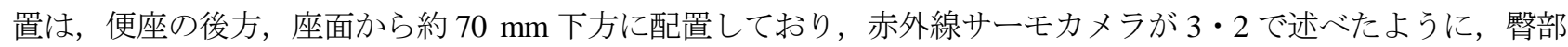
を撮影できるよう便座の下に配置されている (図 6(a)). 
3 章で述べた肛門検出システムによって算出された值が PIC に送られると，トイレユニットを乗せた土台が， 肛門の位置まで移動する。このとき赤外線サーモカメラは横に移動し，トイレユニットに干渉しない位置まで運 ばれる，その後，トイレユニットを臀部に密着させるため，上方向に移動をする（図 6(b))．排泄が終了し処理が 終わった後は, 同様の経路をたどり下降, 後進をして初期位置に戻る.

\section{$4 \cdot 2$ 移動機構の構造}

移動機構の外観を図 7 に示寸．本機構にはトイレユニットを乗せる土台があり，その台を前後・上下に移動さ せるアクチュエータを設置している，どちらのアクチュエータも構造は同じであり，ステッピングモータ

（MERCURY MOTOR 製 ST-42BYG020）とボールねじを使った一軸アクチュエータで，前後移動用は土台の側 面側に，上下移動用は土台の背面にそれぞれ配置した (図 7(b)). また, 赤外線サーモカメラは前後移動用のアク チュエータ側に設置し, 図6(a)に示すように, 土台の前後移動に追従して横方向に移動するようになっている.

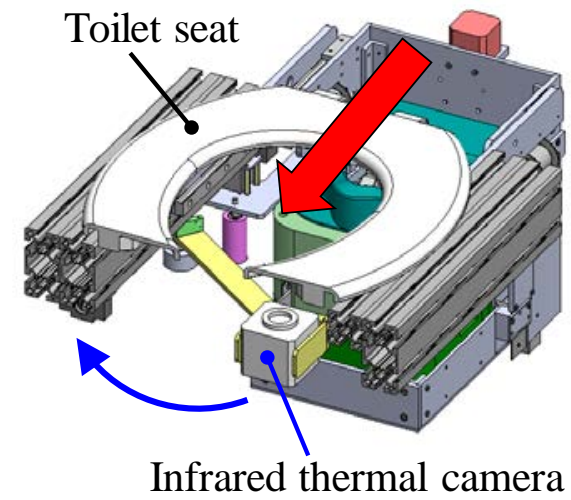

(a) Forward displacement

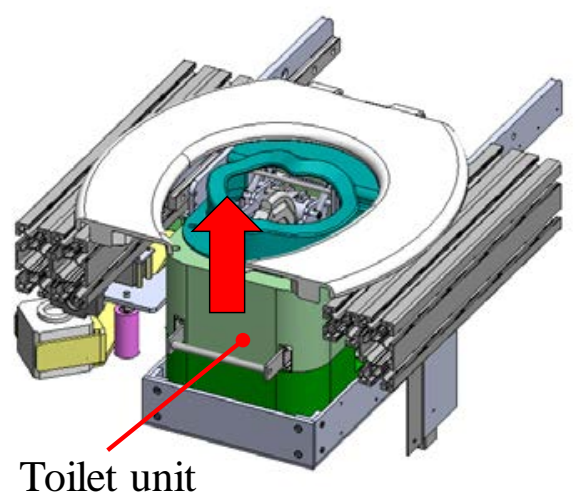

(b) Upward movement

Fig. 6 Operation of movement mechanism

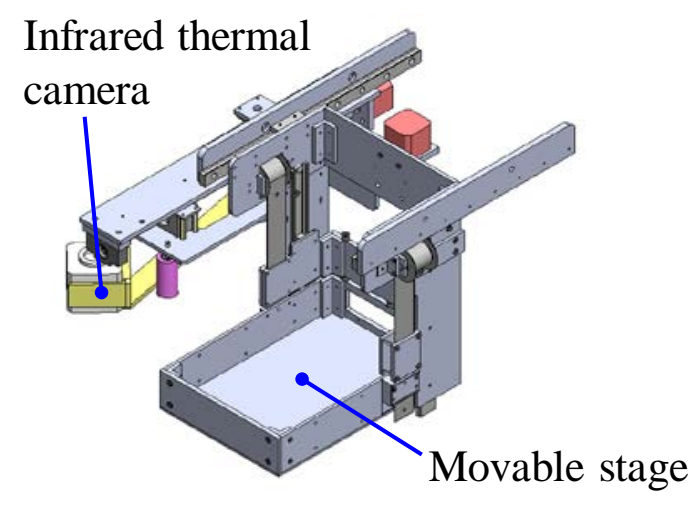

(a) Overview (obverse side)

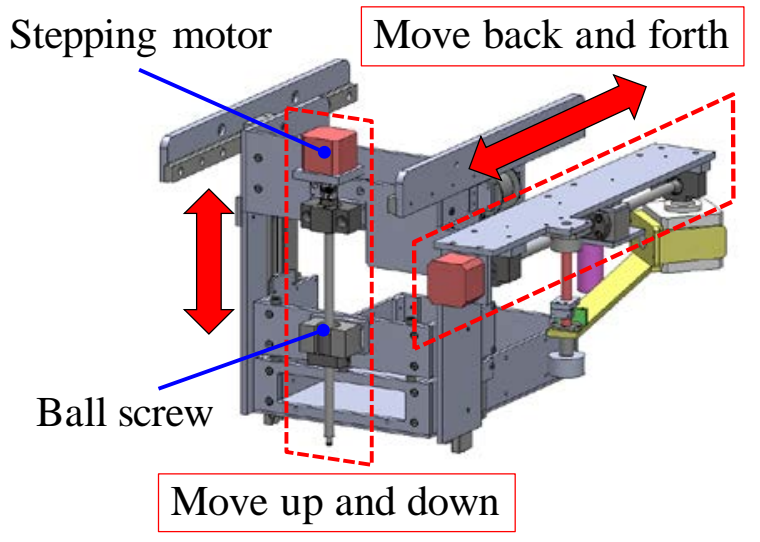

(b) Reverse side

Fig. 7 Mechanical structure of the movement mechanism

\section{5. トイレユニット}

\section{$5 \cdot 1$ トイレユニットの概要}

図 8 にトイレユニットの全体構成を示す. 本ユニットは, 密着部 (Fitting cover), 熱圧着部（Heat sealer）, 清 拭機構部 (Wiping machine), 泡生成機構部（Foam maker), そして本体ケース（Case）からなる. ユニットの内 
部には骨格となるフレームがあり，清拭機構部と熱圧着部，泡生成機構部を固定し（図 8(b)），周りを ABS 樹脂 製のケースで覆い，上部分に慰部への密着部を配置している（図 8(a)）.

使用する際には，まず排泄物を収容するためのビニール製の袋をユニットの中に取りつけ，肛門の污れを拭き 取るためのウエットティッシュを清拭機構部の清拭部に両面テープで貼り付けておく.そして使用者がトイレシ ステムの便座に座った後, 3 章の肛門検出システムと 4 章の移動機構によりトイレユニットを臂部に密着させる.

密着後, 排泄する前に泡生成機構部から送られた泡を肛門に付着させる. 袋内に排泄した後, 再び泡を肛門に付 け，清拭機構によりウエットティッシュを付けた清拭部を肛門の下から押し当てるようにして動かし，污れをウ エットティッシュに付着させながら拭き取る，このとき，慰部をこすらないように拭くことで，皮膚が傷つかな いようにしている．清拭完了後，ユニット前方にある取手を引いて袋の口を熱圧着部により閉じる．使用後は排 泄物の入った袋をユニットから取り出し， ウエットティッシュを清拭部から剥がして回収して，おむつなどと同 様の方法でごみとして廃棄する.

トイレユニットの各部の詳細について以下に述べる.

\section{$5 \cdot 2$ トイレユニットの各部構造}

\section{$5 \cdot 2 \cdot 1$ 密着部}

密着部は慰部に密着させる部分で，排泄時に臭気が外気に拡散することを防ぐ．そのため密着部の形状は人間 の臀部形状に合わせる必要がある。そこで非接触ハンディ 3D スキャナ（Artec Group 製 Artec MHT）を用いて人 間の臀部を測定し，得られた表面形状データをもとにCAD 上で設計を行った.

また人間は排便時に息み，腹圧で直腸を押寸ことで便を排出している（図 9)。このとき直腸がある程度下がる ため, 肛門周辺の臀部も押されて形状が変化しており, 変化する臀部の範囲は骨盤の形状（坐骨，尾てい骨の位 置）に影響している（Tokoro, et al., 2013）。臀部形状が大きく変化した場合, 密着部がずれるなどして臭いが漏れ る可能性がある，そこで排便時の臀部形状変化に対応させるため，骨盤の形状を参考に設計をした．

骨盤の形状は男女で違いがあり, 男性の骨盤に比べ女性の骨盤は尾骨が後方にあり, 坐骨の間隔が広くなって いる (図 10)。これらの違いを考慮して密着部は, 図 11 に示すように男性用と女性用の 2 種類製作した. 製作は 設計した CAD データを基に，3D プリンタ（Stratasys 社製 Dimension BST 768, 材料：ABS 樹脂）で造形し，皮 膚に触れる上面は軟らかいシリコン樹脂で覆う。

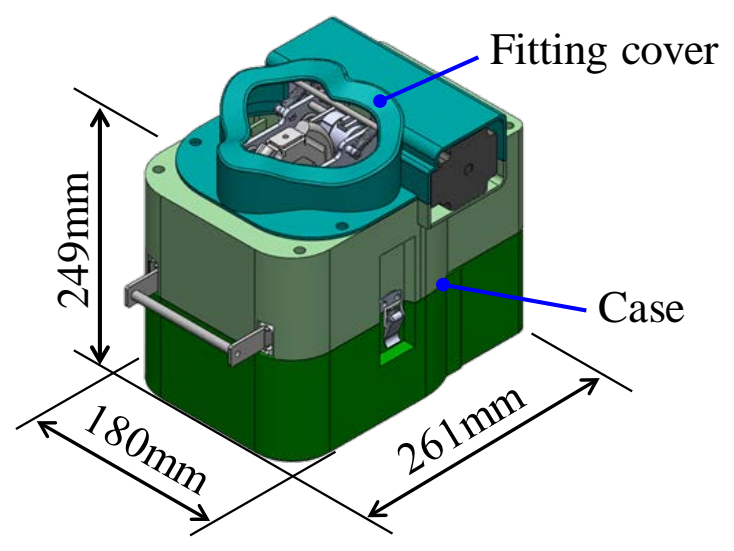

(a) Overview

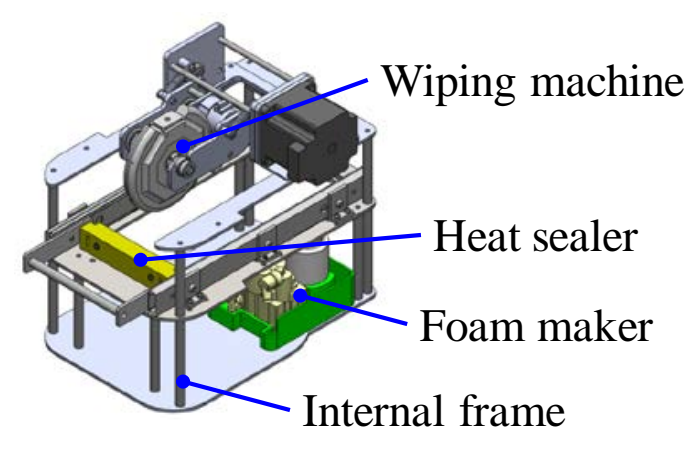

(b) Internal configuration

Fig. 8 Mechanical structure of the toilet unit 


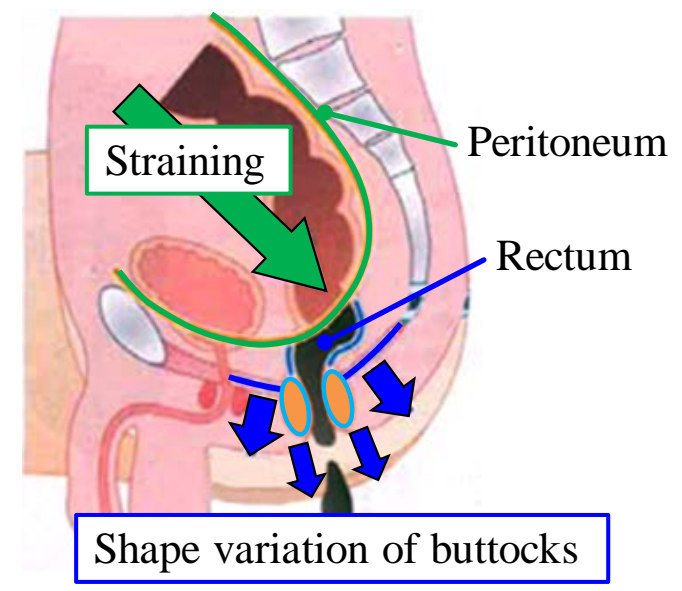

Fig. 9 Act of defecating

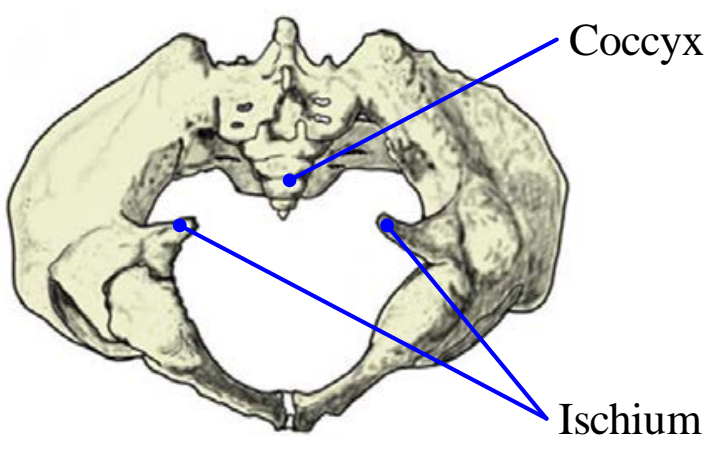

(a) Male

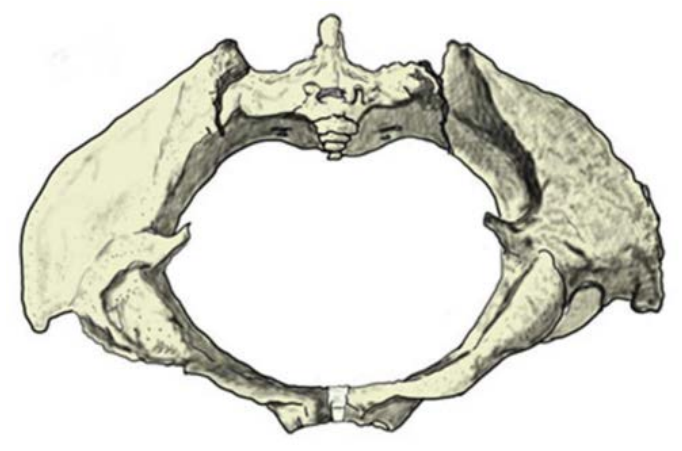

(b) Female

Fig. 10 Pelvic floor

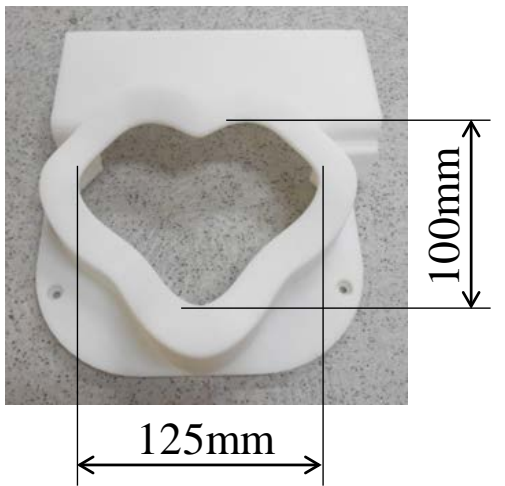

(a) Male

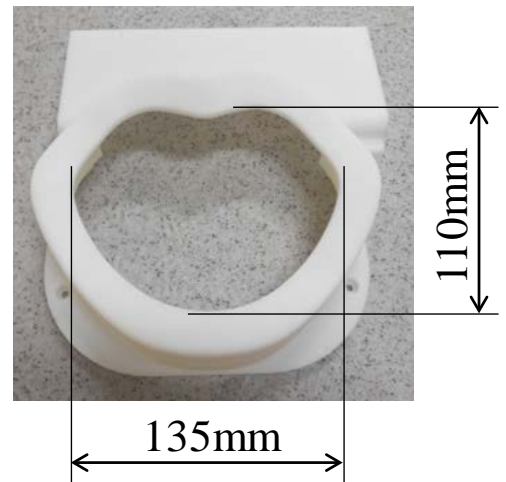

(b) Female

Fig. 11 Fitting cover

\section{$5 \cdot 2 \cdot 2$ 熱圧着部}

熱圧着部は，排泄物収納用の袋（ビニール製）の口を熱圧着させて閉じ，袋からの臭気の漏れを防ぐ．構成は 図12(a)に示すように，ヒートシーラー，移動用スライドレール，取手から成る．取手を引き，袋の口をヒートシ ーラー部分で挟むことで，スイッチが入り，袋を密閉できる（図 12(b)）。これにより，排泄物の入った袋を処理 するときも，臭いが拡がることを防げる. 


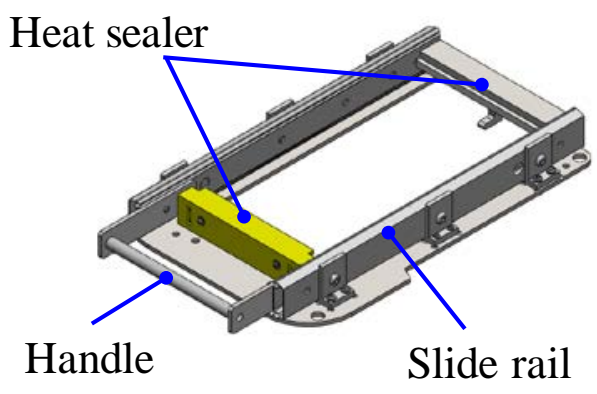

(a) Mechanical structure

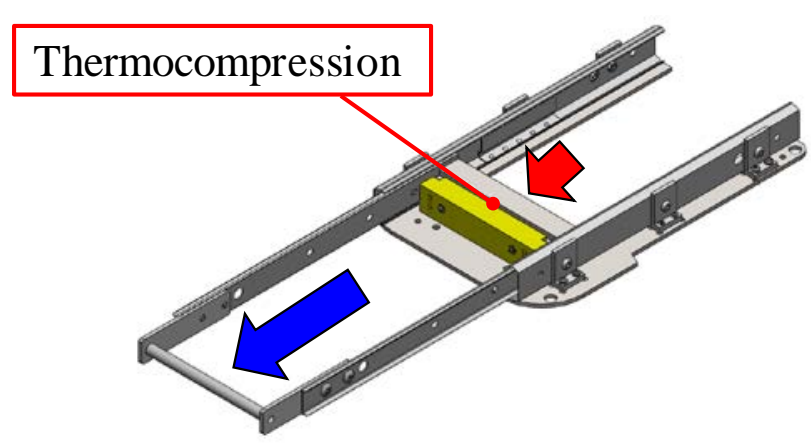

(b) Operation of Heat sealer

Fig. 12 Heat sealer

\section{$5 \cdot 2 \cdot 3$ 清拭機構部}

清拭機構部は，本機構に取り付けたおしり拭き用のウエットティッシュを押し付けることで肛門の污れを拭き 取る機構で (図 13(a)), 体が不自由な方でも介護者の手を借りることなく, 装置によって臀部の清拭が可能にな ることを目的としている．また，後述の泡生成機構部から送られた泡を排泄の前後で肛門に付着させることで污 れを取れやすく寸る (図 13(b)). トイレシステム使用後, 污れたウエットティッシュを取り外し，新しいものに 交換する.

本機構部の構造を図 14 に示す. ウエットティッシュを取り付け, 害際に肛門に触れて污れを拭き取る清拭部, 清拭部を回転させる回転機構部，そして清拭部をリンク機構で上下に移動させるための上下機構部から成る.

清拭部は 3D プリンタにより ABS 樹脂で製作した円盤状のもので, 泡生成機構につながるチューブを取り付け てある. 円盤の側面にはウエットティッシュを両面テープで貼り付け，また側面には一か所，泡を出すための穴 があり，泡を細かくするためにフィルターを取り付けている（図 15(a)）。清拭する際には，回転機構部により回 転することで肛門との接触面を変え， 1 枚のウエットティッシュで複数回清拭を行う. 泡を出して肛門に付着さ せる面は平らであり，それ以外の清拭する面は断面が半円形状となっている．接触面の大きさを縦 $30 \mathrm{~mm} \times$ 横 20 $\mathrm{mm}$ 程度として, 污れを拭き取った面が再び慰部に接触しないよう回転角度を調整し， 1 枚のウエットティッシ ュで最大 7 回清拭できるようにした（図 15(b)).

回転機構部は, タイミングプーリ，タイミングベルト，そしてステッピングモータ SPG27-1702（日本電産コパ ル株式会社製) で構成している. また上下機構部は, 動力にステッピングモータ ST-42BYG020 (MERCURY MOTOR

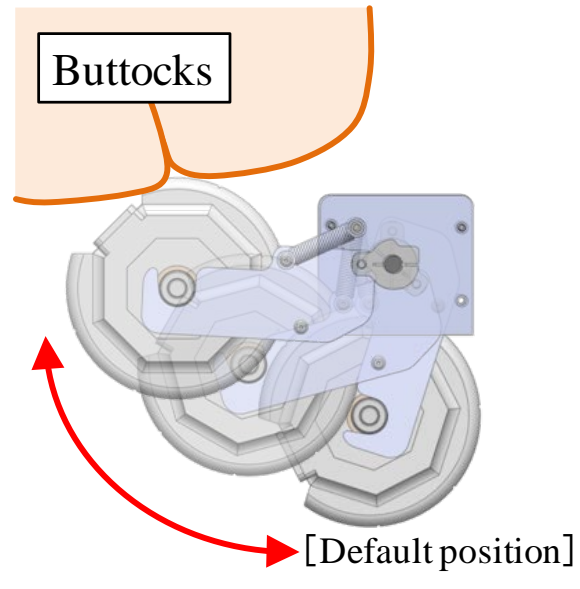

(a) Wiping of buttocks

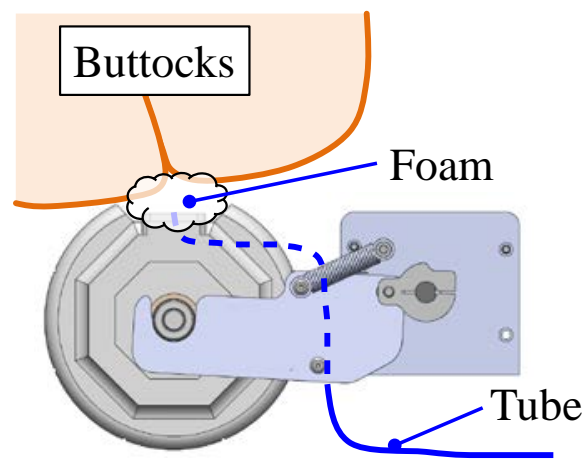

(b) Putting soap foam on buttocks

Fig. 13 Operation of wiping machine 


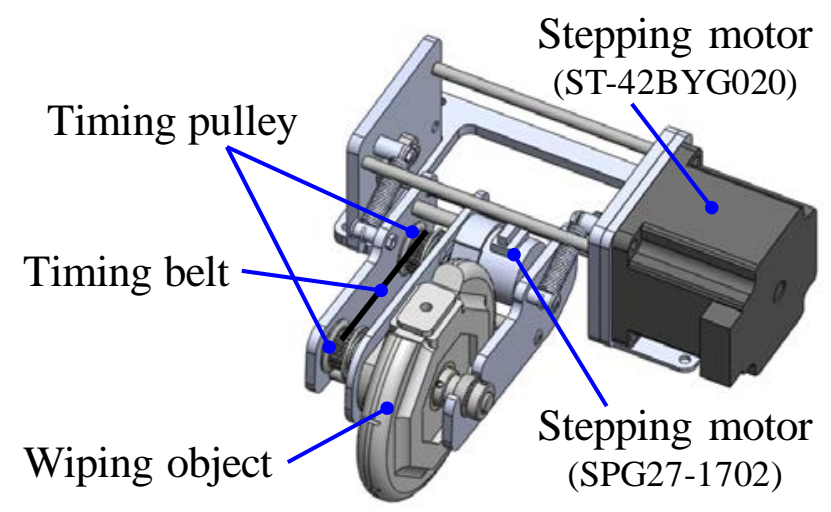

Fig. 14 Mechanical structure of wiping machine

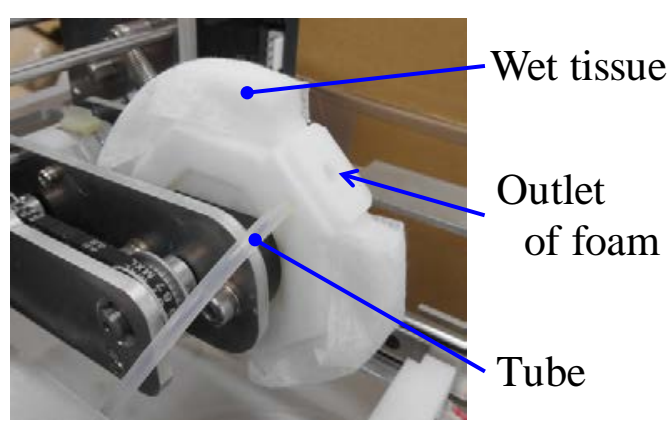

(a) Outline view

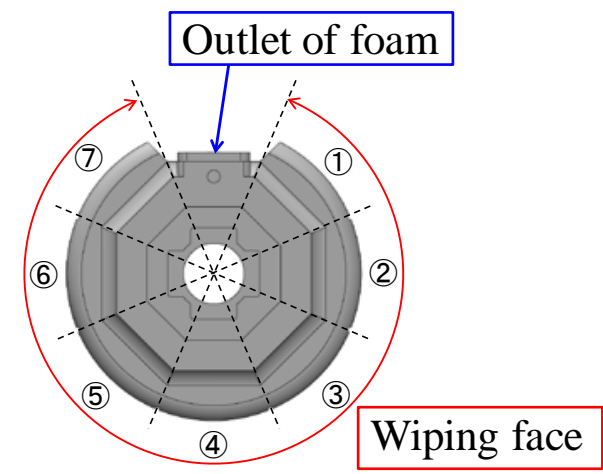

(b) Contact face

Fig. 15 Wiping object

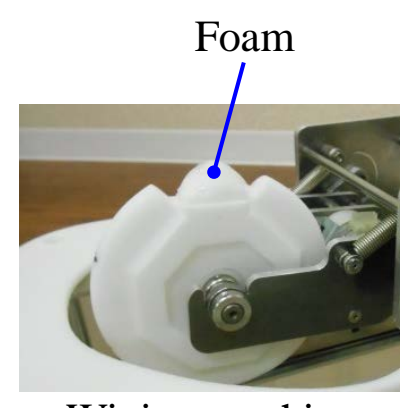

Wiping machine

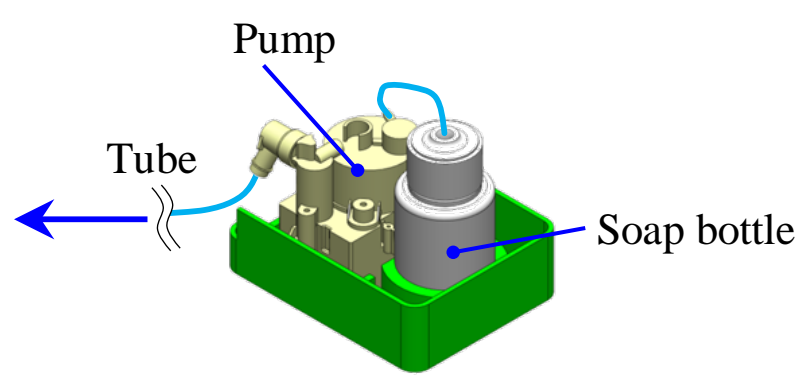

Foam maker

Fig. 16 Mechanical structure of foam maker

製）を使用している，清拭部の初期位置は下に下がった位置で（図 13(a)），泡を付着させる，または清拭を行う 際に，上下機構で上に移動する．清拭時，清拭部が押す力は，ひとまず経験的に約 $4 \mathrm{~N}$ とした．泡付着後あるい は清拭後に，初期位置に戻り，回転機構で次の面に切り替える.

\section{$5 \cdot 2 \cdot 4$ 泡生成機構部}

泡生成機構部の構成を図 16 に示寸. 泡生成機構部には電動式のポンプがあり, モータ駆動で空気とボトルに入 った液状清拭剂を，チューブを通して清拭部に送る，送られた空気と清拭剂が混ざり，清拭部のフィルターを通 ることで細かい泡を作る。この泡を清拭機構部で肛門に付着させる. 
排泄前に肛門に泡を付着させることで，皮膚表面を湿らせ，泡で覆い，便が付着しても剥離しやすく，また便 を出やすくする．さらに排泄後にも泡を付けることで，付着した便を泡で湿らせて水溶させ，吸水性のあるもの

（ウエットティッシュ）に污れを吸着させやすくする.

\section{6. 清拭の評価実験}

\section{$6 \cdot 1$ 実験概要}

トイレユニットでは，肛門に泡を付着させ，清拭部を押し当てることで污れを取り除く，そこで，泡の有無に よる污れの除去性能を比較することで，泡を使った清拭方法の有効性の評価を行った．本実験では，人間で実際 に使用する前に, 人間の臀部形状を模擬した模擬臂部と臀部に污れを付けるための模擬便を用いて実験を行った. 人間の代わりにこれらのモデルを使うことで，いつでも実験ができ，清拭の状況や污れの状態を確認することが 容易に行える. 以下に，模擬慰部と模擬便について述べる.

\section{$6 \cdot 1 \cdot 1$ 模擬殽部}

模擬壂部は，ウレタン樹脂で造形した臀部部分と ABS 樹脂製の土台から成る（図 17）。臂部部分は，人間（成 人男性）の臀部を 3D スキャナで計測し，得られた表面形状データを基に製作した。形状データから臀部の型を 3D プリンタにより製作し， ウレタン樹脂（株式会社エクシールコーポレーション製 人肌のゲル原液 硬度 5）で 造形した，サイズは，肛門を中心に直径 $176.0 \mathrm{~mm}$ ，厚さ $10.0 \mathrm{~mm}$ とし，密着部（男性）より大きくし，余分な部 分はカットした. 肛門部分は模擬便を押し出した時に便の直径が人間と同様の約 $30 \mathrm{~mm}$ になるよう穴を開け，ま た肛門管の代わりとなる筒を内側に作り，模擬便を通せるようにした，土台部分は模擬臂部をトイレユニットの 密着部に固定するためのもので，慰部の型と同様に3D プリンタで製作した.

\section{$6 \cdot 1 \cdot 2$ 模擬便}

模擬便は，便器の洗浄性評価用に開発されたものを参考に製作した（川本他，2007a，2007b)．主な材料は，米 みそ, オクタン酸, 水であり, これらを混ぜ合わせたものに調粘剤としてヒュームドシリカ（日本アロエジル製 ア ロエジル 200）を入れることで，様々な状態の便を再現できる.

便の種類は，ブリストル排便スケールによると (O'Donnell, et al., 2010), 便の硬さや表面の状態から 7 段階に分 けることができ，模擬便ではヒュームドシリカの量を調節することで各段階の便を再現することができる．本実 験では， 7 段階のうち最も標準的な 4 番目「普通便」(表面がなめらかで, 適度な軟らかさの便）を使用した（図 18).このときの各材料の配分量は, みそ $50.0 \mathrm{~g}$, オクタン酸 $2.3 \mathrm{~g}$, 水 $47.7 \mathrm{~g}$ のとき(合計 $100 \mathrm{~g}$ ), 調粘剤である ヒュームドシリカは $5.0 \mathrm{~g}$ となっいる.

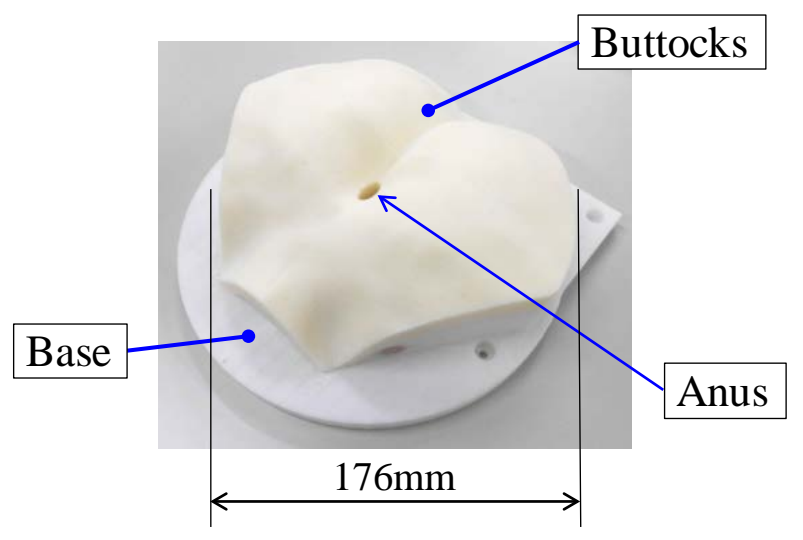

Fig. 17 Artificial buttocks

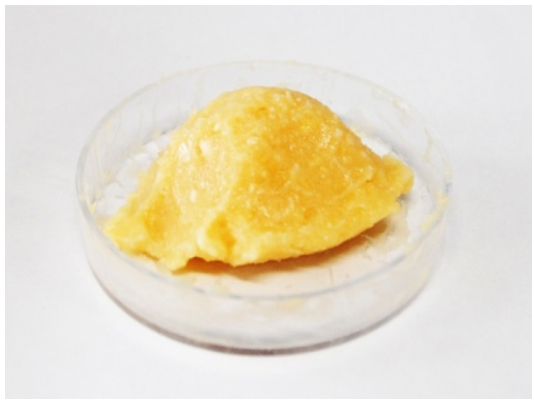

Fig. 18 Artificial stool 


\section{$6 \cdot 2$ 実験方法}

実験の様子を図 19 に示す. まず模擬臂部をトイレユニットの密着部に取り付け, 肛門部分から模擬便を押し出 し，最後に肛門を閉じることで，肛門周辺に模擬便が付着した状態（肛門が污れている状態）にする．このとき， 模擬便は約 $2 \mathrm{~g}$ 付着させた. その後, トイレユニットの清拭機構部によって清拭動作を行い, 污れを拭き取る. 清拭動作完了後, 清拭機構側と模擬臂部側, 両方の状態を確認し, 污れの取れ具合などを見ることで評価を行う.

泡を使わない場合（泡なし）と泡を使った場合（泡有り）で実験を行い，污れの取れ具合から清拭機構と泡の 有効性の評価を行った，泡なし，泡有りでの手順の違いを以下に示す.

・泡を使わない場合（泡なし）：

(1)模擬便を排出（污れを付ける） - (2)清拭動作を実行 - (3)清拭完了

・泡を使った場合（泡有り）：

(1)肛門に泡を付着 - (2)模擬便を排出（污れを付ける） - (3)再び泡を付着 - (4)清拭動作を実行 - (5)清拭完了

上述のとおり，泡を使った場合は，模擬便を排出させる前後で泡を付けることで，肛門および付着した模擬便 に泡が付くようにしている.

清拭機構部の清拭動作で行う，模擬臂部の拭き取り回数については，事前に清拭の実験を行ったところ，泡の 有無にかかわらず 28 回以上清拭を行っても, それ以降ウエットティッシュに污れが付かなかったため, 本実験で は「1枚のウエットティッシュで拭き取れる回数 7 回」×「ウエットティッシュ 4 枚分」の合計 28 回まで清拭す ることとした.

実験は，泡を使わない場合と使った場合，それぞれ 5 回ずつ行い，清拭完了後の状態確認では，清拭機構部側 では污れを拭き取ったウエットティッシュの状況を，模擬慰部側では密着部内の臀部表面を確認し，次節で述心゙ る評価を行った.

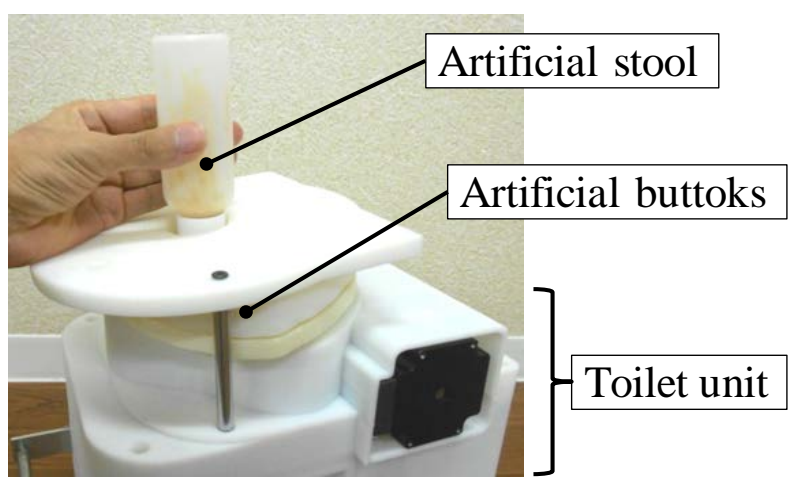

Fig. 19 Experimentation

\section{$6 \cdot 3$ 評価方法}

泡を使った清拭による污れの除去性能を評価するにあたって，污れを拭き取った回数（清拭回数）を比較する ことにした．また事前に動作確認を行った際，模擬臂部に付着させた污れ（模擬便）を清拭機構部で拭き取らせ たときに，污れが十分に取れず，臀部側で押し広げてしまい，污れの面積が拡がる場合があった，そこで今回， 污れの除去性能を見るもう一つの要素として，清拭完了後に猎部に残った污れの面積を見ることにした.

清拭完了後のウエットティッシュの状態例を図 20 に，模擬臂部側の状態例を図 21 に示す。これらの画像から (1) 清拭回数と, 污れの面積から求めた(2) 污れの残留率を調べた. 以下にそれぞれの值の詳細を述べる.

(1) 清拭回数 : 污れを拭き取った回数

清拭完了後, 清拭部に取り付けたウエットティッシュを確認して, 28 回清拭したうち, 図 20(i) (vi)に示すよう に模擬便の污れが付いていた回数を調べる. 


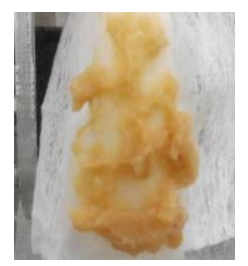

(i)

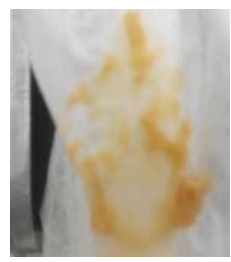

(ii)

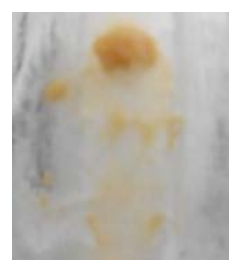

(iii)

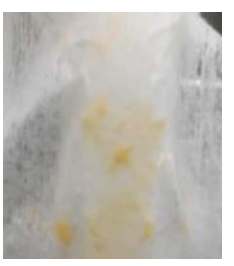

(iv)

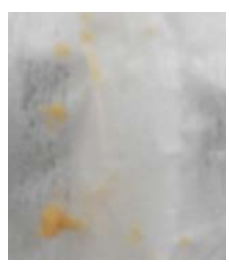

(v)

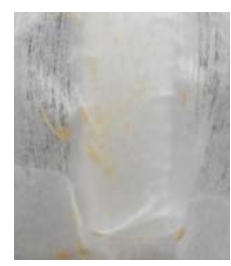

(vi)

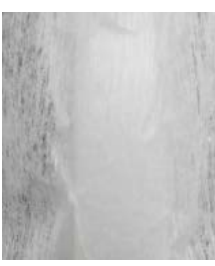

(vii)

Fig. 20 Wet tissue after wiping (from 1 to 7 )

(2) 污れの残留率 : 臀部に付着したままの模擬便による污れの面積

清拭完了後の慰部を図 21 のように正面から撮影し，その写真画像（画像サイズ : $640 \times 480$ pixel）から, 密着 部を取り付けた状態で見える慰部全体の面積と，模擬便で污れている部分の面積を調べ，臀部全体に対する污れ 部分の割合を調べる．模擬慰部の写真画像から，密着部（図 21 : 周りの白い部分）を切り取り，図 22(a)に示す ような残った部分を臀部全体とし, 次にその臂部全体から, 肛門周辺の污れている部分を図 22(b)のように切り抜 き，污れ部分として，それぞれの切り出した画像の pixel 数を面積とした.

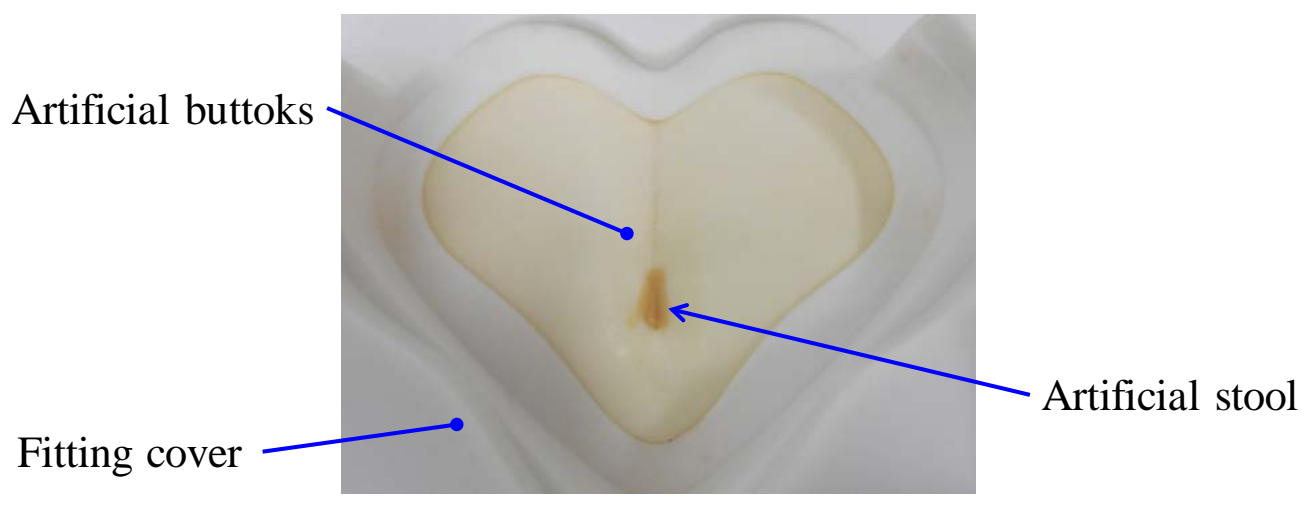

Fig. 21 Artificial buttocks after wiping

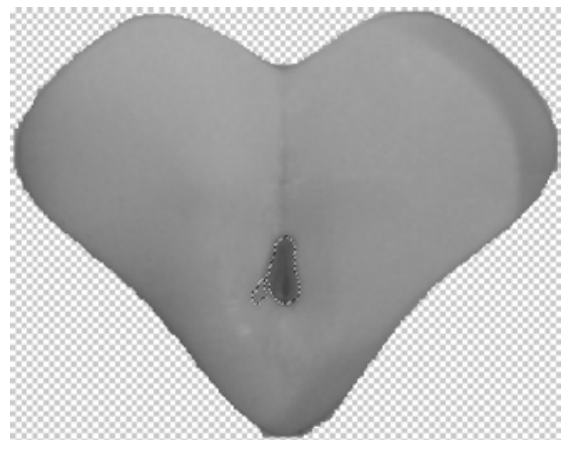

(a) Total surface area

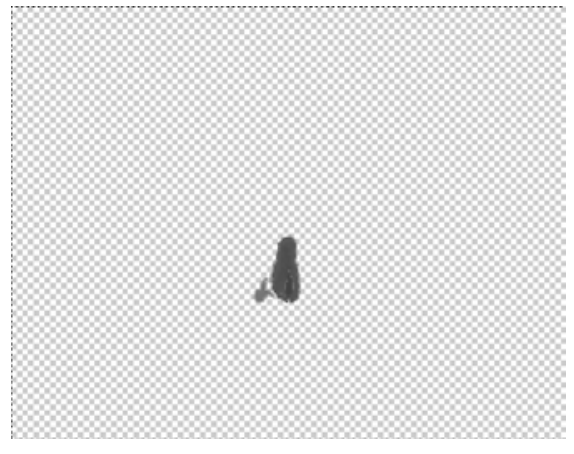

(b) Filthy area

Fig. 22 Picture processing

\section{$6 \cdot 4$ 実験結果}

表 1 に泡を使わない場合（No.1 5）と使った場合（No.6 10），それぞれ 5 回ずつ合計 10 回実験を行ったとき の，(1) 清拭回数と, 慰部の污れ部分の面積, 慰部全体の面積, そしてその面積から求めた(2) 污れの残留率の結 果を示す.また，図23 のグラフには，横軸を清拭回数，縦軸を残留率としたときの関係を示す. 
Tokoro and Kobayashi, Transactions of the JSME (in Japanese), Vol.81, No.824 (2015)

Table 1 Number of wipes and Residual percentage

\begin{tabular}{|c|c|c|c|c|c|}
\hline & \multirow[b]{2}{*}{$\begin{array}{c}\text { Experimental } \\
\text { run number }\end{array}$} & \multirow{2}{*}{$\begin{array}{c}\text { (1) } \\
\text { Number } \\
\text { of wipes } \\
\text { [times] }\end{array}$} & \multicolumn{3}{|c|}{ (2) Residual percentage } \\
\hline & & & $\begin{array}{c}\text { Filthy area } \\
\text { [pixel] }\end{array}$ & $\begin{array}{c}\text { Total surface area } \\
\text { [pixel] }\end{array}$ & {$[\%]$} \\
\hline \multirow[t]{6}{*}{ without foam } & No.1 & 11 & 707 & 35149 & 2.01 \\
\hline & No.2 & 5 & 500 & 35185 & 1.42 \\
\hline & No.3 & 21 & 1339 & 34870 & 3.84 \\
\hline & No.4 & 17 & 2189 & 35506 & 6.17 \\
\hline & No.5 & 26 & 2508 & 34947 & 7.18 \\
\hline & Average & 16.0 & - & - & 4.12 \\
\hline \multirow[t]{6}{*}{ with foam } & No.6 & 7 & 437 & 35644 & 1.23 \\
\hline & No.7 & 10 & 743 & 35457 & 2.10 \\
\hline & No.8 & 8 & 806 & 32226 & 2.50 \\
\hline & No.9 & 4 & 300 & 34741 & 0.86 \\
\hline & No.10 & 3 & 293 & 35597 & 0.82 \\
\hline & Average & 6.4 & - & - & 1.50 \\
\hline
\end{tabular}

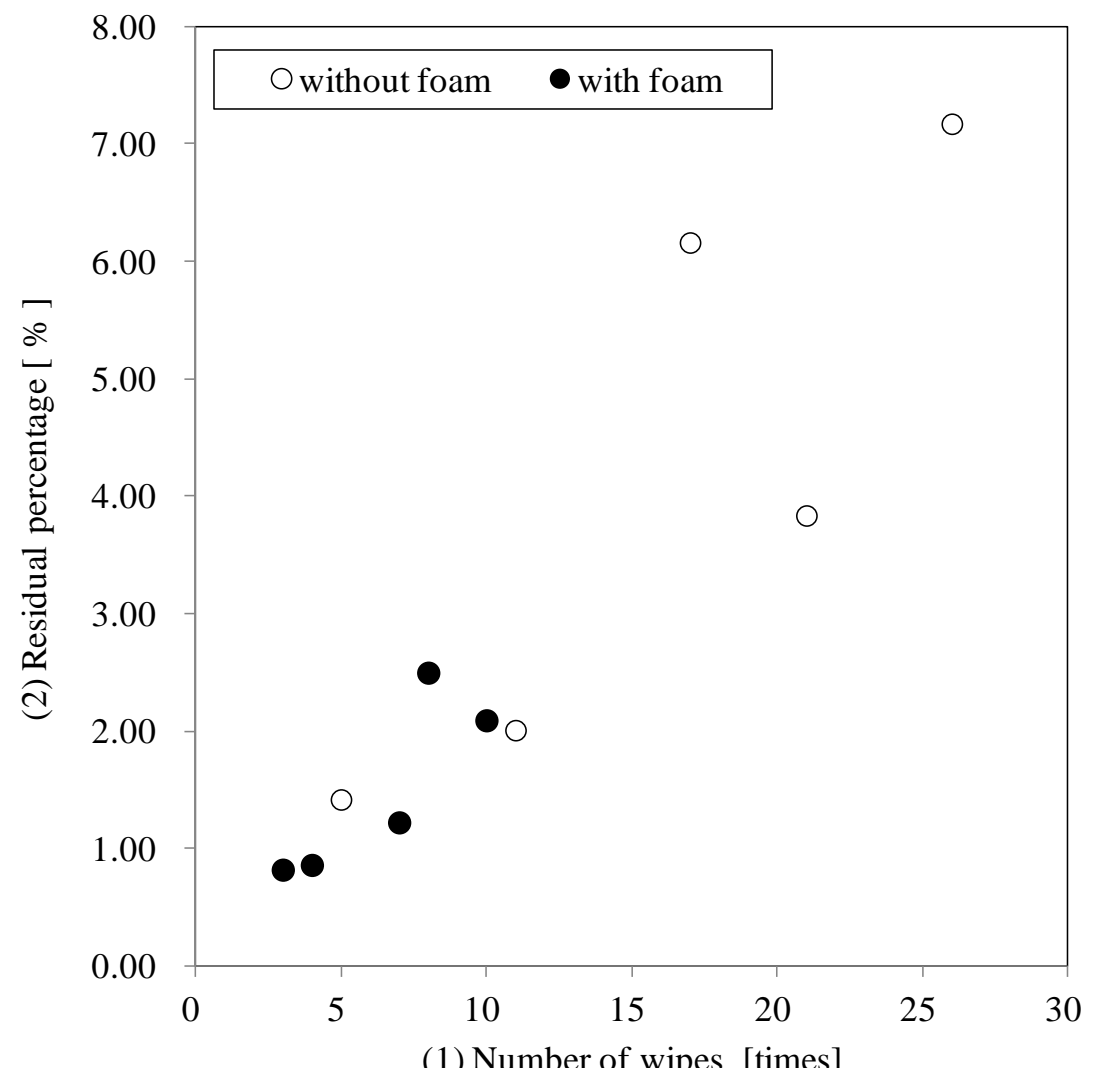

Fig. 23 Number of wipes and Residual percentage

泡を使わない場合, 清拭回数は平均 16.0 回で, 残留率の平均值は $4.12 \%$ となった. No.2 のように清拭回数が 5 回で污れの残留率が $1.42 \%$ と, ウエットティッシュに污れが付き，拭き取れている回数が少なくても，ある程度 污れを取り除いている場合がある一方, No.5 のように清拭回数 26 回と多く拭き取っていても, 残留率が 7.18\% 
と十分に污れを取り除いていない場合があった。これは清拭部でウエットティッシュを污れに押し付けても，污 れがほとんどティッシュ側に吸着せず，慰部に付着したまま取り除くことができなかったためだと思われる.

これに対して泡を使った場合, 清拭回数は平均 6.4 回, 残留率は $1.50 \%$ となっており, どちらも泡を使わない 場合に比べて值が半分以下となっている，これは，泡を使用することで，污れが取れやすくなり，しっかりと拭 き取れるようになったと考えられる，また泡を使った場合においても，No.10 のように清拭回数が少なく，かつ 残留率が少ないものと, No.7 のように比較的清拭回数が多く, 残留率も多くなっている場合があるが, 図 23 の グラフを見ると, 泡を使わない場合の值のばらつきに比べ, 泡を使った場合の值はばらつきが小さくなっており， 清拭回数と残留率が共に少なくなっていることがわかる.

以上のことから，排便の前後で肛門に泡を付着させることで，少ない拭き取り回数でも十分に污れを取り除く ことができることがわかる，これらは，5・2・4で述べたように，泡を付けることによって，肛門が泡で覆われ， 便が剥離しやすくなることに加え, 便が水溶して, ウエットティッシュに污れが吸着させやすくなったからだと 考えられる.

\section{7. 結 言}

本研究では，寝たきりの高齢者でも自立して排泄を行なえる介護用トイレシステムの開発を行なった．本トイ レシステムは, 排泄物を収容するトイレユニットを利用者の慰部に密着させることで, 臭いが拡がることを防ぎ, 確実に排泄物を回収できることに加え, 肛門の清拭も行うことができる. このとき肛門の位置を特定する必要が あるため, 肛門とその周りの温度差を利用した赤外線サーモカメラを用いた肛門検出システムを使用している. そして, トイレユニットを肚門位置まで運ぶ移動機構により, 自動でトイレユニットを臀部に密着させることを 可能にした，トイレユニットでは，臀部との密着部の形を，骨盤の形状の違いから男女別に製作し，また排泄物 を入れる袋を熱による圧着で密閉できるようにした. 次に, 自動で肛門を洗浄する清拭機構を製作し，おしり拭 き用のウエットティッシュを押し付けることで肛門の污れを拭き取れるようにした. さらに，泡を肛門に付着さ せることで, 污れを取れや寸くなるなどの効果があると考え, 泡生成機構を導入して排泄の前後に泡を付着でき るようにした.

この清拭機構と泡を使った肛門の洗浄方法について, 模擬臂部および模擬便を用いた清拭実験を行い，泡の有 効性の評価を行った。清拭実験では, 模擬臂部の肛門に模擬便による污れを付け, 清拭機構による清拭動作を行 ってこの污れを拭き取らせた. そして, 污れを拭き取った清拭回数と模擬臂部に残った污れの残留率を調べ, 泡 を使わない場合と泡を使った場合とで比較を行ったところ，泡を使った場合の方が，清拭回数と残留率がともに 小さくなっており, 少ない拭き取り回数でしっかりと污れを拭き取っていることが分かった.これは泡によって, 便が剥離しやすくなり，また水溶してウエットティッシュに吸着しやすくなったからだと考えられる.

今後は, 泡の量や設置面積などを変えることで泡による洗浄性がどのように変わるかを検証し, 最適な状態を 模索する．また，本トイレシステムでは，トイレユニットを臀部に密着させ，排泄後に熱圧着機構で袋を密閉す ることで臭いの拡散を防ぐことを想定している. そこで, 臭いに関する検証も行っていく. そして, 介護用トイ レシステム全体の評価を, 実証試験を通して行っていく.また, 最終的には, 自立生活サポートシステムと連動 し，寝たきりの方の自立排泄動作の実証試験を行い，本システムの実用性を検証していきたい.

\section{文献}

Fujimoto, T., Hashimoto, T., Sakaki, H., Higashi, Y., Tamura, T. and Tsuji, T., Automated handling system for excretion, Proceedings of the 20th Annual International Conference of the IEEE Engineering in Medicine and Biology Society, Vol. 20, No 4 (1998), pp.1973-1974.

原田祐維, 小林 宏, 臥位から歩行を可能にする自立支援サポートシステムの開発, 第 14 回 計測自動制御学会シ ステムインテグレーション部門講演会 2013(SI2013)講演概要集 (2013), 3J2-4.

Homma, K., Yamada, Y., Matsumoto, O., Ono, E., Lee, S., Horimoto, M., Suzuki, T., Kanehira, N., Suzuki, T. and Shiozawa, S., A proposal of a method to reduce burden of excretion care using robot technology, Proceedings of 2009 IEEE International Conference on Rehabilitation Robotics (ICORR) (2009), pp.621-625. 
石川敦丈，高橋良彦，自立排泄支援を目的とした移乗ロボットシステム，日本機械学会関東支部総会講演会講演 文集, Vol.9 (2003) , pp.135-136.

板倉朋世, 光田恵, 棚村壽三, 高齢者のおむつ交換時における排泄物の臭気特性に関する研究, Journal of environmental engineering, Vol.73, No.625 (2008), pp.335-341.

川本早高, 田中清隆, 北村仁史, 模擬便, 特開 2007-No. 315974 (2007a).

川本早高, 山本透, 神田橋毅, 田中清隆, 北村仁文, 自動洗浄便器の防污性評価法, 松下電工技報, Vol.55, No.4 (2007b), pp.104-109.

菊池有紀, 薬袋淳子, 島内節, 在宅重度要介護高齢者の排泄介護における家族介護者の負担に関連寸る要因, 国際 福祉医療大学紀要, Vol.15, No.2 (2011), pp.13-23.

松田直樹, 舟山裕士, 高橋賢一, 肛門伸展張力計の開発, 日本大腸肛門病学会雑誌, Vol.59, No.8 (2006), pp.427-430.

厚生労働省, 平成 25 年度 厚生労働白書 (2013a), p.232.

厚生労働省, 平成 25 年度 高齢社会白書 (2013b), p.2.

O'Donnell, L J., Virjee, J. and Heaton, K W., Detection of pseudodiarrhoea by simple clinical assessment of intestinal transit rate, British Medical Journal (International Edition), Vol.300, Issue 6722 (1990), p.439.

所 晃史, 小林 宏, 新型トイレシステムと排泄ロボットの開発, ロボティクス・メカトロニクス講演会 2012 講演 概要集 (2012), 2A2-U08.

Tokoro, K., Fujihira, K. and Kobayashi, H., Development of anal position detecting system for new-toilet system, Proceedings of the 2013 7th International Conference on Sensing Technology (2013), pp.52-55.

Tokoro, K., Hashimoto, T. and Kobayashi, H., Development of new toilet system, Proceedings of the 1st Annual IEEE Healthcare Innovation Conference of the IEEE EMBS (2012), pp.105-108.

上野創造, 今井陽介, 早坂智明, 大久保眞彦, 石川拓司, 山口隆美, 自走式排泄支援システムの開発, 福祉工学シ ンポジウム講演論文集 (2008), pp.176-177.

吉本和樹, 施設で排泄援助を受ける高齢者の体験, 日本老年看護学会誌, Vol.13, No.1 (2008), pp.57-64.

Yukawa, T., Nakata, N., Obinata G. and Makino, T., Assistance system for bedridden patients to reduce the burden of nursing care (First report - Development of a multifunctional electric wheelchair, portable bath, lift, and mobile robot with portable toilet), 2010 IEEE/SICE International Symposium on System Integration (SII 2010)(2010), pp.132-139.

\section{References}

Fujimoto, T., Hashimoto, T., Sakaki, H., Higashi, Y., Tamura, T. and Tsuji, T., Automated handling system for excretion, Proceedings of the 20th Annual International Conference of the IEEE Engineering in Medicine and Biology Society, Vol. 20, No 4(1998), pp.1973-1974.

Harada, Y. and Kobayashi, H., Development of an independence support system capable of walking from recumbent position, 14th SICE System Integration Division Annual Conference (2013), 3J2-4 (in Japanese).

Homma, K., Yamada, Y., Matsumoto, O., Ono, E., Lee, S., Horimoto, M., Suzuki, T., Kanehira, N., Suzuki, T. and Shiozawa,S., A proposal of a method to reduce burden of excretion care using robot technology, Proceedings of 2009 IEEE International Conference on Rehabilitation Robotics (ICORR) (2009), pp.621-625.

Ishikawa, N. and Takahashi, Y., Transfer assist robot system for independence excretion support, Transactions of the Japan Society of Mechanical Engineers Kanto Branch, Vol.9 (2003), pp.135-136 (in Japanese).

Itakura, T., Mitsuda, M. and Tanamura, T., Reseach on characteristics of the odors from excrement at the adult diaper exchange [in Japanese], Journal of environmental engineering, Vol.73, No.625 (2008), pp.335-341 (in Japanese).

Kawamoto, S., Tanaka, K. and Kitamura, H., Simulated waste, Japanese Unexamined Patent Application Publication No. 2007-No. 315974 (2007a) (in Japanese).

Kawamoto, S., Yamamoto, T., Kandabashi, T., Tanaka, K. and Kitamura, H., Evaluation method of stain protection performance of automatic cleaning toilet, Matsushita Electric Works technical report, Vol.55, No.4 (2007b), pp.104-109 (in Japanese).

Kikuchi, Y., Minai, J. and Shimanouchi, S., Factors of caregiver burden related with incontinence of the dependent elderly at home, Annals of the International University of Health and Welfare, Vol.15, No.2 (2011), pp.13-23 (in Japanese).

Matsuda N., Funayama Y. and Takahashi K., Development of anal stretching tensionmeter, The Journal of the Japan Society of Colo-Proctology, Vol.59, No.8 (2006), pp.427-430 (in Japanese).

Ministry of Health, Labour and Welfare, Annual health, labour and welfare report 2012-2013 (2013a), p.232 (in Japanese) 
Ministry of Health, Labour and Welfare, Annual report on the aging Society:2013 (2013b), p.2 (in Japanese)

O'Donnell, L J., Virjee, J. and Heaton, K W., Detection of pseudodiarrhoea by simple clinical assessment of intestinal transit rate, British Medical Journal (International Edition), Vol.300, Issue 6722 (1990), p.439.

Tokoro, K. and Kobayashi, H., Development of new toilet system and defecation robot, 2012 JSME Conference on Robotics and Mechatronics (2012), 2A2-U08 (in Japanese).

Tokoro, K., Fujihira, K. and Kobayashi, H., Development of anal position detecting system for new-toilet system, Proceedings of the 2013 7th International Conference on Sensing Technology (2013), pp.52-55.

Tokoro, K., Hashimoto, T. and Kobayashi, H., Development of new toilet system, Proceedings of the 1st Annual IEEE Healthcare Innovation Conference of the IEEE EMBS (2012), pp.105-108.

Ueno, S., Imai, Y., Hayasaka, T., Okubo, M., Ishikawa T. and Yamaguchi, T., Development of a mobile toilet system, Proceedings of the Welfare Engineering Symposium (2008), pp.176-177 (in Japanese).

Yoshimoto, K., Experience of elderly people receiving excretion assistance in the care facilities, journal of Japan Academy of Gerontological Nursing, Vol.13, No.1 (2008), pp. 57-64 (in Japanese).

Yukawa, T., Nakata, N., Obinata G. and Makino, T., Assistance system for bedridden patients to reduce the burden of nursing care (First report - Development of a multifunctional electric wheelchair, portable bath, lift, and mobile robot with portable toilet), 2010 IEEE/SICE International Symposium on System Integration (SII 2010)(2010), pp.132-139. 